\title{
Groundwater Pollution Due to Agricultural Activity in Hosakote Taluk, Bangalore Rural District, Karnataka, India: A Case Study
}

\author{
Shivanna $\mathbf{S}^{\mathbf{1}}$, Vyshnavi D $\mathbf{R}^{\mathbf{1}}$ and Sriram Mustapure ${ }^{2}$ \\ 1. Department of Civil Engineering, Sir MVIT, Bangalore - 562157 \\ 2. Department of Civil Engineering, EWCE, Bangalore- 560064
}

\begin{abstract}
The present study highlights the impact of increased agricultural activity on groundwater in Hosakote taluk, Bangalore Rural district, Karnataka, India. The study area lies between the Lat. $12^{\circ} 50^{\prime}$ and $13^{\circ} 25^{\prime}$ and Long. $77^{\circ} 35^{\prime}$ to $78^{\circ} 00^{\prime}$ with an aerial extent of 548 square kilometers The results are based on the chemical analysis of groundwater samples. The Bangalore metropolis being close to the study area, it depends on the life support on the suburbs. As a result, farmers of the study area have shifted from the traditional agricultural practices to cash crops such as fruits, vegetable and floriculture, which is more lucrative. This has paved way for overexploitation of groundwater without proper management. The indiscriminate use of chemical fertilizers, insecticides and pesticides for increased production has resulted in pollution of groundwater. The chemical constituents such as $\mathrm{Na}, \mathrm{K}, \mathrm{Cl}, \mathrm{SO}_{4}$ and $\mathrm{NO}_{3}$ show the increase anomaly in the study area. These anomalies can be related to the excess use of fertilizers and pesticides in the agricultural practices, which has deteriorated the groundwater quality. The deterioration of the water quality if more localized in nature and can be overcome by judicious usage of chemical fertilizers and pesticides.

Keywords:Groundwater, Pollution, Agrochemical, Landuse, Hosakote
\end{abstract}

\section{Introduction}

The increased agricultural activities have polluted groundwater to an extent which needs attention before it attains a point of non-return. The present day increase in agricultural activity to meet the food grains target of growing population has adversely affected the quality of water as well as land. The economic interest in agriculture has pushed the ecological importance of agricultural activity to the background. Due to urbanization about 12-12.5 million hectares of fertile land is lost each year around the globe resulting in more stress on available land for usage causing over-exploitation and degradation due to various agricultural activities. Thus, agrochemicals input has become a source of pollution to the groundwater. The usage of fertilizers and pesticides in agricultural practices by developed countries is far more than developing countries like India, but due to non-judicious usage it has become a primary source of contamination of groundwater in developing countries. The usage of fertilizers and pesticides is more in case of horticulture than agriculture in contaminating the groundwater. The close proximity of the study area to Bangalore metropolis has given thrust in developmental activity in Hosakote taluk both on industrial and agricultural fronts. The metropolis depends for life support particularly for fresh fruits, vegetable, flowers etc, on its suburbs. As a consequence, this the farmers in the study area have shifted from traditional crops to more lucrative cash crops to meet the city demands. Thus, resulting in over-exploitation of groundwater, with indiscriminate usage offertilizers and pesticides causing pollution.

\section{Location}

Hoskote taluk is in Bangalore rural area and forms the eastern part of the district. It falls in the Survey of India (SOI) toposheet Nos. 57 G/12, 57 G/16, 57 $\mathrm{H} / 9$ and $57 \mathrm{H} / 13$ and lies between $12^{\circ} 51^{\prime}$ to $13^{\circ} 15^{\prime}$ N.Latitude and $77^{\circ} 41^{\prime}$ to $77^{\circ} 58^{\prime} \mathrm{E}$ Longitude, covering an area of 602 sq.km (Fig.1). Physiographically, the area is characterized by undulating terrain. The highest elevation is found near Nandagudi hill, which rises $940 \mathrm{~m}$ above the 
MSL. The low-lying valleys and depressions are intensely cultivated and sloping towards southern part of the taluk. The area under present study is 25 kms from Bangalore metropolis to Bangalore Chenni National Highway passes through. The nearest airport is Kempegowda International Airport, Bangalore.

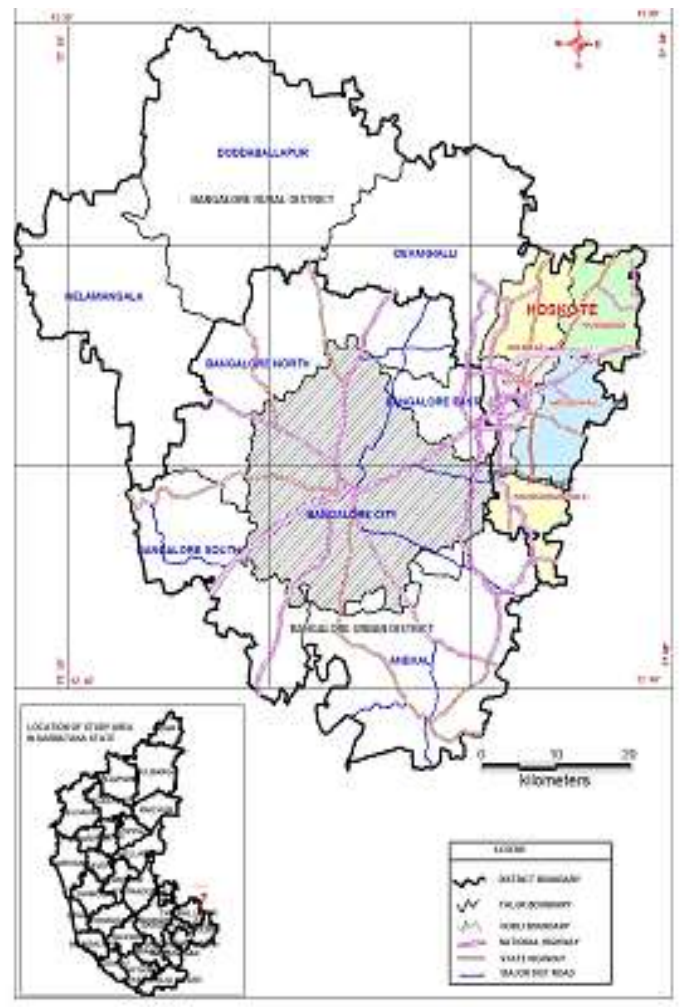

Fig.1: Location Map of HoskoteTaluk, Bangalore rural district.

\section{Geology and Soils}

The study area is comprised of crystalline, hard and massive rocks and are devoid of primary porosity, but the joints, fractures and fissures act as reservoir and conduits for groundwater percolation. The contact zones between gneiss and granite, granitic gneiss and laterites have proved to be more successful for groundwater occurrences in the study basin. The lateritic outcrops are exposed as mounds and hillocks which rise from 20 to $80 \mathrm{~m}$ above the surrounding area. In the weathered and pegmatite veins the groundwater occurs in unconfined condition. Also, in the jointed and fissured zones, groundwater will be present. The weathered granitic layers and fractured layers are two distinct aquifers and no connection exits with each other (Radhakrishna, et.al 1974, Ballukaraya, and Ravi 2008). Groundwater movement is controlled by lineaments, dykes and quartz veins. The lineaments serve as conduits for movement of groundwater, whereas dykes and quartz veins obstruct movement of groundwater. The yield of wells in the study basin depends on intensity of weathering and spacing of primary joints. The depth to bedrock ranges from 20 to $30 \mathrm{~m}$. in granitic and gneissic terrain, 60 to $20 \mathrm{~m}$ in lateritic areas.

The rock formations in the study area are granitic gneisses which are of migmatite type. Laterites are seen as isolated patches capping the crystalline hard rocks. The soils in the area are lateritic and lateritic gravely. These have an average infiltration rate of $2.00 \mathrm{cms} /$ hour and $4.20 \mathrm{cms} /$ hour respectively.

\section{Climate}

Physiographically Hoskote taluk shows an undulating topography with gentle slope towards South-west. The general elevation of the ground is around 870 in above MSL. The highest elevation is noticed near Nandagudi, which rises above $940 \mathrm{~m}$ MSL. Hoskote taluk enjoys a pleasant climate with mild summers and pleasant winters. The summer temperature touches $37^{\circ} \mathrm{C}$ during May and the winter temperature around $19^{\circ} \mathrm{C}$ during December/January. The relative humidity is around $77 \%$ during monsoon and 50\% during dry months. The taluk receives an average rainfall of $750 \mathrm{~mm}$.

\section{Methodology}

The discussion and interpretations are based on the chemical analyses of water samples from the study area Hosakote taluk. The water samples were analyses for constituents viz. $\mathrm{Ca}, \mathrm{Mg}, \mathrm{Na}, \mathrm{K}, \mathrm{Cl}$, $\mathrm{SO}_{4}, \mathrm{NO}_{3}, \mathrm{HCO}_{3}$, TDS, EC and $\mathrm{pH}$. The statistical parameters of water quality data have been shown in Table 1.

\section{Landuse and Agricultural Practices}

The area in the present study was basically a traditional agriculture practicing area growing crops such as paddy, ragi, jowar, sorghum, maize etc. utilizing rainfall and lately by groundwater. The population boom, industrialization and consequent rapid growth of Bangalore metropolis has shrunk the agricultural land on the periphery of the city which was once a source for fresh fruits, vegetables etc. Hence the stress fell on the suburbs of the metropolis for growing fruits and vegetable. This has resulted in shifting over to cultivation of cash crops, which is more lucrative than the traditional crops. Table 2 shows the increasing trend of land usage for horticulture, pesticide and fertilizer outlets and numbers of energized wells in Hosakote taluk.

The increase in agricultural activity has also increased the draft of groundwater. The density of 
energized wells varies between $80-110$ well/sq kms. Paving way for over-exploitation of groundwater without any conservation or management technique. As a result of this, over-exploitation of groundwater levels has gone down and the taluk has been declared as dark area by the governmental agencies for further developmental activities.

\section{Results and Discussion}

The groundwater samples collected were analyses for the constituents like $\mathrm{Ca}, \mathrm{Mg}, \mathrm{Na}, \mathrm{K}, \mathrm{Cl}, \mathrm{SO}_{4}$, $\mathrm{NO}_{3}, \mathrm{HCO}_{3}$, TDS, EC and $\mathrm{pH}$. The constituents such as $\mathrm{Na}, \mathrm{K}, \mathrm{Cl}, \mathrm{SO}_{4}$ and $\mathrm{NO}_{3}$ show anomalous zones The reason for the anomaly in the study area is due to excess usage of pesticides and chemical fertilizers such as N-fertilizers, NPK, Potash etc in landuse. Though lithology does contribute to some extent for the anomalies, the other source being traditional manure obtained from plant and animal waste. The unused fertilizer compounds, pesticides and animal manure are carried down by the percolating water into the aquifer contaminating the groundwater to a large extent.

The sodium anomaly is seen in and around Hosakote town. The average value in the area is $56.6 \mathrm{mg} / \mathrm{ltr}$. ranging from $10-262 \mathrm{mg} / \mathrm{ltr}$. The source being from weathering of litho-units but major contribution is from chemical fertilizers and animal waste used in agricultural practices.

The potassium anomaly is also seen in and around Hosakote town. The average value is $17.2 \mathrm{mg} / \mathrm{ltr}$. ranging from $1-50 \mathrm{mg} / \mathrm{ltr}$. The source of potassium is from weathering of lithunits and agricultural activities. The usage of organic fertilizers like NPK and traditional manure obtained from plant and animal waste contribute potassium to groundwater.

The anomalies of in case of chlorides is in and around Hosakote town. The average chloride value in the study area is $128.9 \mathrm{mg} / \mathrm{ltr}$., with a range of 11 $495 \mathrm{mg} / \mathrm{ltr}$. The contribution of chloride to groundwater is from the usage of organic fertilizers such as K-fertilizers and manure, rather than lithology in the present scenario.

The sulphates are usually derived from litho-units and of late from atmosphere, dissolved during the rainfall in a very highly industrially polluted area and percolates into the aquifers. The anomaly seen in the taluk is in and around Hosakote town, which is due to accumulation by the addition of organic fertilizers in agricultural practices. The average value is $40.7 \mathrm{mg} / \mathrm{ltr}$, ranging from 5 to $290 \mathrm{mg} / \mathrm{ltr}$.
The source of nitrate in the groundwater is due to man's interaction with his environment, the other sources are meagre. The anomalous zones are seen in and around Hosakote town. The excess usage of chemical fertilizers, pesticides/insecticides and animal waste in agricultural practices contribute nitrate to the groundwater. The average value id $17 \mathrm{mg} / \mathrm{ltr}$., ranging from $3-55 \mathrm{mg} / \mathrm{ltr}$. The nitrate in the anomaly zones is due to fertilizers, manure and nitrogen fixing bacteria. The unused or unutilized components of fertilizers in the soil percolates polluting the aquifer.

\section{Conclusion}

The present study reveals that the quality of groundwater in Hosakote taluk though suitable for agricultural practices is contaminated by the excess usage of chemical fertilizers and pesticides, which will have adverse effect on human health, particularly the nitrates. The contaminations are local in nature in the study area. This trend can be arrested by judicious usage of agricultural inputs. The quantum and time of application of agro-inputs and their advantages are to be highlighted to the farming community in the study area.

Earlier the water was drawn from shallow aquifers and was found to be safe and potable. As years passed on, there are various developmental activities. Industries have been set up in and around Hosakote town and industrial area has also been established. Erratic use of fertilizers and pesticides in the agricultural sectors, the usage of bore well water enormously increased and drawing water from greater depths resulted in contamination of water.

Table 1: Water Quality Data of Hosakote Taluk

\begin{tabular}{|l|l|l|l|l|}
\hline Constituents & Max. & Min. & Mean & SD \\
\hline $\mathrm{Ca}$ & 188 & 18 & 78.4 & 45.3 \\
\hline $\mathrm{Mg}$ & 58 & 10 & 27 & 14.5 \\
\hline $\mathrm{Na}$ & 262 & 10 & 56.6 & 57.4 \\
\hline $\mathrm{K}$ & 50 & 1 & 17.2 & 31.3 \\
\hline $\mathrm{Cl}$ & 495 & 11 & 128.9 & 124 \\
\hline $\mathrm{SO}_{4}$ & 290 & 5 & 40.7 & 59.1 \\
\hline $\mathrm{NO}_{3}$ & 51 & 3 & 17 & 12.4 \\
\hline $\mathrm{HCO}_{3}$ & 466 & 95 & 245 & 97.3 \\
\hline $\mathrm{TDS}^{\mathrm{E}}$ & 1420 & 117 & 599.2 & 366.4 \\
\hline $\mathrm{EC}$ & 2250 & 180 & 919.9 & 573.7 \\
\hline $\mathrm{pH}$ & 8.9 & 7.1 & 7.7 & 0.4 \\
\hline All the values in $\boldsymbol{m}$ g/ltr, except EC and pH \\
\hline
\end{tabular}


Table 2: Land utilization for various Horticulture crops (Area in Hectares)

\begin{tabular}{|l|l|l|l|l|l|}
\hline Year & $\begin{array}{l}\text { Fruit } \\
\text { Orcha } \\
\text { rds }\end{array}$ & $\begin{array}{l}\text { Veget } \\
\text { able }\end{array}$ & $\begin{array}{l}\text { Flor } \\
\text { i- } \\
\text { cult } \\
\text { ure }\end{array}$ & $\begin{array}{l}\text { No. of } \\
\text { Fertilize } \\
\text { r outlets }\end{array}$ & $\begin{array}{l}\text { No. of } \\
\text { Energi } \\
\text { sed } \\
\text { wells }\end{array}$ \\
\hline 1980 & 666 & 442 & 26 & 19 & 6990 \\
\hline 1985 & 845 & 607 & 37 & 38 & 9834 \\
\hline 1990 & 936 & 2155 & 85 & 89 & 12521 \\
\hline 1995 & 1237 & 3110 & 140 & 117 & 14108 \\
\hline 2000 & 1357 & 3800 & 186 & 126 & 16110 \\
\hline 2005 & 1412 & 3980 & 210 & 139 & 18210 \\
\hline 2015 & 1456 & 4200 & 250 & 158 & 19334 \\
\hline 2020 & 1590 & 4643 & 278 & 213 & 20145 \\
\hline
\end{tabular}

\section{Acknowledgments}

Dr Shivanna S and Mrs. Vyshnavi D R are thankful to the Management of Sri Krishnadevaraya Educational Trust, Bangalore and Prof. H.P. Mahendra Babu, Head of the Department of Civil Engineering, Sir M Visvesvaraya Institute of Technology, Bangalore for the support and encouragement.

\section{References}

[1] Hem J D: Study and interpretation of chemical characteristics of natural water., Paper No. 1473, GSWS, US Govt. Printing Press, Washington (1967).

[2] Pionke H B and Urban J B: Effects of agricultural landuse on groundwater quality in a small Pennsylvania watershed., Groundwater, Vol.23, No. 1., pp.68-80., (1989)

[3] Piskin R: Evaluation of nitrate content of groundwater in Hall County, Nebraska., Groundwater, Vol.11., No.6., pp. 4-13., (1973).

[4]Ballukraya, $\mathbf{P} \mathbf{N}$ and Ravi, R: Natural fresh water ridges as barrieragainst sea water intrusion in Chennai City. Jour. Geol. Soc. India, Vol. 67, pp 95116., (2008)

[5] Radhakrishna, B.P., Dusanduba and Palmquist, WN: Groundwater development in hard rock areas of Karnataka State, India. Bull. No.150, Pub., Dept. of Mines and Geology, Government of Karnataka., (1974).

[5] Stephen C $\mathbf{K}$ and Henry W A: Nitrogen isotopes as indicators of nitrate source in Minnesoto Sand-Plain aquifers., Groundwater., Vol.31, No.2., pp. 260-270., (1993). 